well as to previous biological therapies. The HRQL variables would be additional clinical results that make it possible to achieve a better management of biological therapies in spondyloarthropathy patients.

Disclosure of Interests: None declared.

DOI: 10.1136/annrheumdis-2021-eular.2282

\section{AB0503 DISEASE CONTROL IN ANKYLOSING SPONDYLITIS PATIENTS WITH PERIPHERAL ARTHRITIS IN REAL CLINICAL PRACTICE IN SPAIN: MIDAS STUDY RESULTS}

X. Juanola ${ }^{1}$, C. Fernández-Carballido ${ }^{2}$, A. Muñoz Jimenez. ${ }^{3}$, J. Sanz ${ }^{4}$, A. Urruticoechea-Arana ${ }^{5}$, P. Moya ${ }^{6}$, J. M. Belzunegui Otano ${ }^{7}$, C. Sanabra ${ }^{8}$, C. Sastré ${ }^{8}$ on behalf of MIDAS group. ${ }^{1}$ Hospital Universitari Bellvitge, IDIBELL, rheumatology service, L'Hospitalet de Llobregat, Barcelona, Spain; ${ }^{2}$ Hospital Universitario San Juan de Alicante, rheumatology service, Alicante, Spain; ${ }^{3}$ Hospital Universitario Virgen Rocío, rheumatology service, Sevilla, Spain; ${ }^{4}$ Hospital Universitario Puerta de Hierro, rheumatology service, Madrid, Spain; ${ }^{5}$ Hospital Can Misses, rheumatology service, Ibiza, Spain; ${ }^{6}$ Hospital de la Santa Creu i Sant Pau, rheumatology service, Barcelona, Spain; ${ }^{7}$ Hospital Universitario de Donostia, rheumatology service, San Sebastián, Spain; ${ }^{8}$ Novartis Farmacéutica, rheumatology, Barcelona, Spain

Background: MIDAS study assessed disease activity in patients (pts) with ankylosing spondylitis (AS) treated in clinical practice in Spain.

Objectives: This subanalysis compared disease activity status between AS pts with and without peripheral arthritis (PA).

Methods: Observational, non-interventional, cross-sectional, multicenter study. Pts $\geq 18$ years with $\geq 6$ months diagnosis, fulfilling ASAS and modified New York criteria; undergoing treatment $\geq 3$ months. Disease activity was measured by BASDAI and ASDAS-CRP. The number of painful and swollen joints was recorded in AS pts according to the OMERACT recommendations.

Results: 313 AS pts included: 251 (80.2\%) without PA and 62 (19.8\%) with PA (Table 1). The most frequently involved painful joints in pts with PA were knees $(29.0 \%)$ and hips $(25.8 \%)$, while the swollen ones were proximal interphalangeal joints of the hands (17.7\%), knees $(9.7 \%)$ and wrists $(8.1 \%)$. According to BASDAI (Figure 1A), pts with PA showed a higher score 4.2 (2.4) and a lower percentage $58.1 \%$ had disease activity controlled (BASDAl $<4)$ than total AS pts (3.1 [2.2] and 64.5\%, respectively) and pts without PA (2.8 [2.1] and 70.1\%, respectively). According to ASDAS-CRP (Figure 1B), mean (SD) score was 1.9 (1.1) for AS pts, 2.4 (1.1) for pts with PA and 1.8 (1.1) for pts without PA, while $29.4 \%$ AS pts, $14.5 \%$ pts with PA and $33.1 \%$ pts without PA had inactive disease (ASDAS-PCR<1.3). By combining both indices (ASDAS-CRP and BASDAI), 51.8\% AS pts showed adequate control (inactive disease/remission) of disease activity, $29.0 \%$ of pts with PA and $57.4 \%$ of pts without PA.

Table 1. Baseline demographic and clinical characteristics of the AS pts

\begin{tabular}{|c|c|c|c|}
\hline & $\begin{array}{l}\text { AS } \\
(n=313)\end{array}$ & $\begin{array}{l}\text { AS without PA } \\
(n=251)\end{array}$ & $\begin{array}{l}\text { AS with PA } \\
(n=62)\end{array}$ \\
\hline Age (years), mean (SD) & $50.4(12.0)$ & $50.1(11.9)$ & $51.5(12.5)$ \\
\hline Sex (male), n (\%) & $237(75.7 \%)$ & $193(76.9 \%)$ & $44(71.0 \%)$ \\
\hline $\begin{array}{l}\text { Time since diagnosis (years), } \\
\text { mean (SD) }\end{array}$ & $15.5(11.6)$ & $15.4(11.4)$ & $16.0(12.6)$ \\
\hline $\begin{array}{l}\text { Time from onset of symptoms } \\
\text { to diagnosis (years), } \\
\text { mean (SD) }\end{array}$ & $5.0(7.2)$ & $4.9(7.1)$ & $5.6(7.6)$ \\
\hline Presence of HLA-B ${ }^{\star} 27+, n(\%)$ & $245(78.5 \%)$ & $197(78.8 \%)$ & $48(77.4 \%)$ \\
\hline Family history of AS, n (\%) & $66(21.1 \%)$ & $55(21.9 \%)$ & $11(17.7 \%)$ \\
\hline $\begin{array}{l}\text { Family history of psoriasis, } \\
\qquad \mathrm{n}(\%)\end{array}$ & $43(13.7 \%)$ & $34(13.5 \%)$ & $9(14.5 \%)$ \\
\hline $\begin{array}{l}\text { Pts previously treated with } \\
\text { bDMARD, } \mathrm{n}(\%)\end{array}$ & $99(31.6 \%)$ & $79(31.5 \%)$ & $20(32.3 \%)$ \\
\hline $\begin{array}{l}\text { Swollen joint count }(0-66) \text {, } \\
\text { mean }(\mathrm{SD})\end{array}$ & $0.1(0.9)$ & $0.0(0.0)$ & $0.7(1.9)$ \\
\hline $\begin{array}{l}\text { Painful joint count (0-68), } \\
\text { mean (SD) }\end{array}$ & $0.6(2.4)$ & $0.0(0.0)$ & $3.0(4.7)$ \\
\hline CRP levels (mg/l), mean (SD) & $5.1(8.2)$ & $4.7(7.6)$ & $6.7(10.3)$ \\
\hline \multicolumn{4}{|l|}{ Active disease, $\mathrm{n}(\%)^{\star}$} \\
\hline BASDAI $\geq 4$ & $111(35.5 \%)$ & $26(41.9 \%)$ & 75 (29.9\%) \\
\hline ASDAS-CRP $\geq 2.1$ & $133(42.4 \%)$ & $93(37.1 \%)$ & $40(64.5 \%)$ \\
\hline BASFI, mean (SD) & $3.4(2.7)$ & $3.1(2.6)$ & $4.5(2.8)$ \\
\hline MASES index, mean (SD) & $0.2(0.8)$ & $0.2(0.7)$ & $0.4(1.2)$ \\
\hline SPARCC index, mean (SD) & $0.4(1.1)$ & $0.3(1.0)$ & $0.6(1.4)$ \\
\hline $\begin{array}{l}\text { Pts perceived disease } \\
\text { control (PASS), } \mathrm{n}(\%)\end{array}$ & $270(86.3 \%)$ & $221(88.0 \%)$ & $49(79.0 \%)$ \\
\hline ASAS-HI, mean (SD) & $5.8(4.4)$ & $5.4(4.2)$ & $7.6(4.6)$ \\
\hline
\end{tabular}

${ }^{*}$ Refers to the percentage of pts with active disease according to BASDAI $\geq 4$ and ASDAS-CRP $\geq 2$. 1 .

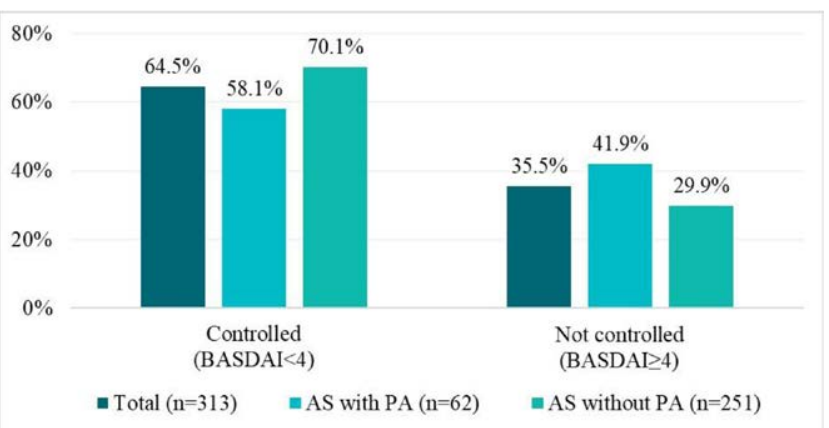

$60 \%$

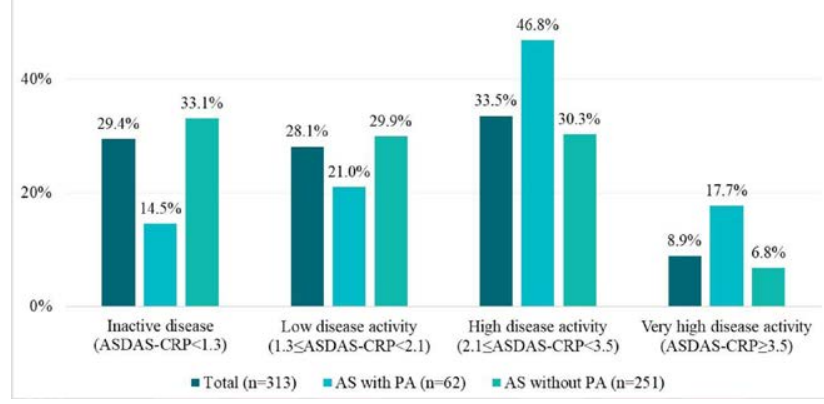

Figure 1. Disease status according to peripheral joints involvementA)Disease control according to BASDAIB)Disease activity according to ASDAS-CRP

Conclusion: Patients of the MiDAS study with peripheral disease showed higher disease activity and worse physical function, suggesting a severe and complex phenotype more than the one of the AS pts without PA.

REFERENCES:

[1] J Rheumatol 1993;20:526-91.

AS, ankylosing spondylitis; ASDAS-CRP, Ankylosing Spondylitis Disease Activity Score- C-reactive protein; BASDAI, Bath Ankylosing Spondylitis Disease Activity Index; PA, peripheral arthritis.

Acknowledgements: We thank to MIDAS group investigators and patients included in the study.

Disclosure of Interests: Xavier Juanola Speakers bureau: Novartis, Abbvie, Pfizer, Lilly, Consultant of: Novartis, Lilly, Abbvie, Cristina Fernández-Carballido Speakers bureau: I have received lectures fees from Abbvie, Celgene, Janssen, Lilly, MSD, Novartis, Pfizer, Roche and UCB., Consultant of: I have worked as a paid consultant for Abbvie, Celgene, Janssen, Lilly, Novartis, Pfizer and UCB., Alejandro Muñoz Jimenez.: None declared., Jesus Sanz Speakers bureau: Abbvie, Janssen-Cilag, Novartis, Lilly, Consultant of: Abbvie, Janssen-Cilag, Novartis Lilly, Amgen, Grant/research support from:Abbvie, ANA URRUTICOECHEA-ARANA Speakers bureau: Abbvie, Bristol, Celgene, Janssen, Lilly, MSD, Novartis, Pfizer and UCB, Consultant of: Abbvie, Bristol, Celgene, Janssen, Lilly, MSD, Novartis, Pfizer and UCB, Patricia Moya Speakers bureau: Abbvie, Novartis and UCB, Consultant of: Roche, Joaquin Maria Belzunegui Otano Speakers bureau: Lilly, Amgen, Novartis, Abbvie, Janssen., Cristina Sanabra Employee of: Novartis employee, Carlos Sastré Employee of: Novartis employee. DOI: 10.1136/annrheumdis-2021-eular.2357

\section{\begin{tabular}{|l|l}
\hline AB0504 TOPOGRAPHY OF 18F-FDG PET/CT INFLAMMATORY \\
\hline
\end{tabular} SITES IN SPONDYLOARTHRITIS IN COMPARISON TO POLYMYALGIA RHEUMATICA AND TO PATIENTS WITHOUT INFLAMMATORY RHEUMATIC DISEASE}

N. Giraud ${ }^{1}$, M. Sondag ${ }^{1}$, M. Chouk ${ }^{1}$, F. Verhoeven ${ }^{1}$, D. Wendling ${ }^{1}$, C. Prati ${ }^{1}$.

${ }^{1}$ University Hospital Besancon, Rheumatology, BESANCON, France

Background: Spondyloarthritis (SpA) is a common inflammatory rheumatism characterized by axial and/or peripheral enthesitis. The positron emission tomography (PET/CT) allows the detection of inflammation.

Objectives: Our objective was to study the rhizomelic fixation with 18F-FDG (18-Fluorine deoxyglucose) PET/CT in SpA, compared to a Polymyalgia Rheumatica (PMR) group and to a control without rheumatological manifestations Methods: Monocentric and retrospective study, including patients who have benefited from PET/CT. 2 groups of patients, with SpA on the one hand, and PMR on the other hand, fulfilling standard diagnostic criteria. A third group of controls (CN) benefiting from PET/CT in the context of assessment of a neoplasia. The rhizomelic fixations were evaluated according to the average of semi-quantitative scores. This in different rhizomelic sites, articular (gleno-humeral, coxo-femoral) and extra-articular (sub acromial (BSAD), trochanteric bursitis).

Results: 147 patients were included: 44 SpA, 50 PMR, and 53 CN. The rhizomelic fixations were significantly lower in SpA compared to PMR: on the pelvic girdle $[0.31(0.7)$ 
vs 1.15(1.04), $\left.p=1.2^{*} 10-10\right]$, the scapular girdle [0.15(0.44) vs. 1.35(1.2), $\left.p=7.09^{*} 10-15\right]$, the hip joints $\left[0.27(0.62)\right.$ vs $\left.1.16(1.16), p=1.6^{*} 10-5\right]$, glenohumeral joints $[0.18(0.49)$ vs. $\left.1.71(1.04), p=4.75^{*} 10-12\right]$, the trochanteric bursae $[0.36(0.77)$ vs $1.14(0.91)$, $\left.\mathrm{p}=3.54^{*} 10-6\right]$, BSADs $\left[0.11(0.38)\right.$ vs. $\left.0.98(1.24), \mathrm{p}=4.63^{*} 10-5\right]$, or overall rhizomelic fixation. [0.23(0.59) vs. 1.26(1.14), $\left.p=4.47^{\star} 10-24\right]$. The fixation was also significantly lower for SpA compared to $\mathrm{CN}$, in trochanters [0.36(0.77) vs $\left.0.58(0.68), \mathrm{p}=3.54^{*} 10-6\right]$, at the glenohumeral joints $\left[0.18(0.49)\right.$ vs $\left.0.58(0.66), p=3.27^{*} 10-5\right]$, pelvic girdle $[0.31(0.7)$ vs. $0.49(0.67), p=0.0028]$ and scapular girdle $\left[0.15(0.44)\right.$ vs. $\left.0.41(0.66), p=7.09^{*} 10-15\right]$ and on the global overall rhizomelic fixation $\left[0.23(0.59)\right.$ vs. $\left.0.49(0.67), p=1.22^{*} 10-6\right]$. Conclusion: Our study is the first to study the rhizomelic fixations with 18f-FDG in SpA, compared to another rheumatism inflammatory and controls. We found a lower fixation in SpA compared to PMR, confirming the major and specific rhizomelic fixation of PMR. We found a lower fixing of SpA compared to $\mathrm{CN}$, without anatomical, articular or extra-articular systematization. SpA seems to be a condition with low uptake on 18f-FDG $\mathrm{PET} / \mathrm{CT}$, particularly at the rhizomelic level, compared to PMR and controls.

Disclosure of Interests: None declared.

DOI: 10.1136/annrheumdis-2021-eular.2444

\section{AB0505 DISEASE FEATURES ASSOCIATED WITH A HIGH DISEASE IMPACT IN AXIAL SPONDYLOARTHRITIS: POST HOC ANALYSIS OF A SINGLE-CENTER CROSS- SECTIONAL STUDY}

R. Queiró Silva ${ }^{1}$, S. Alonso Castro ${ }^{1}$, L. C. Charca Benavente ${ }^{1}$, M. Pino Martínez ${ }^{1}$, S. Burger ${ }^{1}$, M. Alperi-López ${ }^{1}{ }^{1}$ Hospital Universitario Central de Asturias, Rheumatology, OVIEDO, Spain

Background: Currently available information on disease factors associated with a high life impact on axial spondyloarthritis (axSpA) is still very limited. Therefore, information on disease factors associated with a high life impact is crucial for the optimal management of this condition.

Objectives: To define disease factors associated with a high disease impact (HDI) in axSpA. Methods: Post hoc analysis of a cross-sectional observational study conducted in 111 consecutive patients diagnosed with axSpA ${ }^{1}$. We defined the Assessment of SpondyloArthritis international Society-Health Index (ASAS HI) functioning and health status groups thresholds using the Ankylosing Spondylitis Disease Activity Score (ASDAS) as external anchor. To establish the ASAS HI cut-off, receiver operating characteristic $(\mathrm{ROC})$ curves of the different activity categories of the ASDAS were constructed. A multivariate analysis was carried out to evaluate the disease factors associated with HDI.

Results: Median ASDAS was 2.1 (IQR: 1.5-2.7). Average score for ASAS-HI was $5.4 \pm 3.8$ (IQR: $3-8$ ). ASAS HI values $>6$, area under the ROC curve $0.86(95 \% \mathrm{Cl}: 0.78-0.92)$, identified the patients belonging to the groups of high-very high disease activity. Among the study population, 69 patients had an ASAS $\mathrm{HI} \leq 6$ while 42 showed an ASAS $\mathrm{HI}>6$ (Table 1). In the multivariate regression model, HLA-B27 [OR $0.15(95 \% \mathrm{Cl}$ : $0.05-0.48)$, $\mathrm{p}=0.001$ ], NSAID intake [OR $5.4(95 \% \mathrm{Cl}: 1.2-23.3), \mathrm{p}=0.023$, and a family history of SpA [OR $3.1(95 \% \mathrm{Cl}: 1.01-10.6), \mathrm{p}=0.043$ ] were independently related to $\mathrm{HDI}$

Table 1. Disease features among patients with and without high disease impact

\begin{tabular}{|c|c|c|c|}
\hline Feature & ASAS HI $\leq 6$ (n: 69) & ASAS HI > $6(n: 42)$ & P-values \\
\hline $\begin{array}{l}\text { Age, yrs (SD) } \\
\text { Disease duration, yrs (SD) } \\
\text { Men, n (\%) } \\
\text { Women, n (\%) } \\
\text { AS, n (\%) } \\
\text { Family history, n (\%) } \\
\text { HLA-B27, n (\%) } \\
\text { Education level }\end{array}$ & $\begin{array}{l}42.7(11.2) \\
7.6(7.5) \\
49(71) \\
20(29) \\
47(68.1) \\
6(8.7) \\
62(89.9)\end{array}$ & $\begin{array}{l}44.3(9.8) \\
7.8(5.2) \\
25(59.5) \\
17(40.5) \\
27(64.3) \\
10(23.8) \\
26(61.9)\end{array}$ & $\begin{array}{l}\text { NS } \\
\text { NS } \\
\text { NS } \\
\text { NS } \\
\text { NS } \\
0.040 \\
0.001\end{array}$ \\
\hline $\begin{array}{l}\text { Education level: } \\
\text {-Primary, n (\%) } \\
\text {-Secondary, n (\%) } \\
\text {-University, n (\%) }\end{array}$ & $\begin{array}{l}25(36.2) \\
20(29) \\
24(34.8)\end{array}$ & $\begin{array}{l}18(42.9) \\
14(33.3) \\
10(23.8)\end{array}$ & NS \\
\hline $\begin{array}{l}\text { CVRF: } \\
\text {-Smoking, n (\%) } \\
\text {-Obesity, n (\%) } \\
\text {-Diabetes, n (\%) } \\
\text {-HBP, n (\%) } \\
\text {-Dyslipidemia, n (\%) }\end{array}$ & $\begin{array}{l}25(36.2) \\
8(11.6) \\
3(4.3) \\
9(13) \\
17(24.6)\end{array}$ & $\begin{array}{l}19(45.2) \\
10(23.8) \\
3(7.1) \\
5(11.9) \\
9(21.4)\end{array}$ & NS \\
\hline $\begin{array}{l}\text { Radiographic features: } \\
\text {-Bilateral SI, n (\%) } \\
\text {-Squaring, n (\%) } \\
\text {-Syndesmophytes, n (\%) }\end{array}$ & $\begin{array}{l}57(82.6) \\
13(18.8) \\
12(17.4)\end{array}$ & $\begin{array}{l}30(71.4) \\
9(21.4) \\
9(21.4)\end{array}$ & NS \\
\hline $\begin{array}{l}\text { SpA-associated features: } \\
\text {-Enthesitis, n (\%) } \\
\text {-Anterior uveitis, n (\%) } \\
\text {-IBD, n (\%) } \\
\text { Fibromyalgia, n (\%) } \\
\text { Depression, n (\%) }\end{array}$ & $\begin{array}{l}7(10.1) \\
12(17.4) \\
2(2.9) \\
0(0) \\
2(2.9)\end{array}$ & $\begin{array}{l}1(2.4) \\
2(2.8) \\
4(9.5) \\
3(7.1) \\
6(14.3)\end{array}$ & $\begin{array}{l}\text { NS } \\
0.045 \\
\text { NS } \\
0.052 \\
0.032\end{array}$ \\
\hline $\begin{array}{l}\text { Treatments: } \\
\text {-NSAID, n (\%) } \\
\text {-DMARDs, n (\%) } \\
\text {-Biologic therapy, n (\%) }\end{array}$ & $\begin{array}{l}50(72.5 \%) \\
4(5.8 \%) \\
40(58)\end{array}$ & $\begin{array}{l}39(92.9) \\
2(4.8) \\
27(64.3)\end{array}$ & $\begin{array}{l}0.013 \\
\text { NS } \\
\text { NS }\end{array}$ \\
\hline
\end{tabular}

ASAS HI:Assessment of SpondyloArthritis international Society-Health Index, yrs: years, SD: standard deviation, AS: ankylosing spondylitis, HLA: human leukocyte antigen, CVRF: cardiovascular risk factors, HBP: high blood pressure, SI: sacroilitis, SpA: spondyloarthritis, IBD: inflammatory bowel disease NSAID: non-steroidal anti-inflammatory drugs, DMARDs: disease modifying antirheumatic drugs.
Conclusion: In this study, patients with regular NSAID intake and those with a positive family history of SpA were more likely to be in a high-impact category according to the ASAS $\mathrm{HI}$. On the other hand, HLA-B27 carriers reduced that possibility by $85 \%$. Our data may contribute to providing more personalized attention focused on patients' needs.

\section{REFERENCES:}

[1] Alonso S, Pardo E, Charca L, et al. Performance of the ASAS health index for the evaluation of spondyloarthritis in daily practice. J Rheumatol 2020; 47 1483-1489.

Disclosure of Interests: None declared.

DOI: 10.1136/annrheumdis-2021-eular.2559

\section{AB0506 PREVALENCE AND CLINICAL CHARACTERISTICS OF SPONDYLOARTHRITIS IN CENTRAL AMERICA AND CARIBBEAN (PRECAES)}

A. Garcia Kutzbach ${ }^{1,2,3}$, P. Camilo Estrella ${ }^{4}$, V. Khoury ${ }^{4}$, H. Alonzo ${ }^{5}$, C. S. Pastelín ${ }^{5}$, G. Guerra Batista ${ }^{6}$, A. Ogdie ${ }^{7}$ on behalf of AGAR team.

${ }^{1}$ Guatemalan Association Against Rheumatic Diseases (AGAR), Rheumatology, Guatemala City, Guatemala; ${ }^{2}$ UFM School of Medicine, Internal Medicine - Rheumatology Section, Guatemala City, Guatemala; ${ }^{3}$ Private Practice, Rheumatology, Guatemala City, Guatemala; ${ }^{4}$ Private Practice, Rheumatology, Santiago de los Caballeros, Dominican Republic; ${ }^{5}$ Private Practice, Rheumatology, Tegucigalpa, Honduras; ${ }^{6}$ Private Practice, Rheumatology, Panama, Panama; ${ }^{7}$ Perelman School of Medicine, University of Pennsylvania, Rheumatology, Philadelphia, United States of America

Background: Spondyloarthritis $(\mathrm{SpA})$ is a group of interrelated disorders: axial spondyloarthritis (Ankylosing Spondylitis [AS]/Non Radiographic Axial Spondyloarthritis $[\mathrm{Nr}-\mathrm{AxSpA}])$, psoriatic arthritis $(\mathrm{Ps} A)$, reactive arthritis $(\operatorname{ReA})$, inflammatory bowel disease-associated arthritis (IBD), and undifferentiated SpA (USpA). ${ }^{1}$

Objectives: The objectives of this study were: a) to examine the epidemiology, disease subsets, and clinical characteristics of patients with SpA in Central America and the Caribbean region; and $b$ ) to describe the natural history of these conditions in their acute and chronic forms, to determine clinical sub-types and severity.

Methods: PRECAES is a cross-sectional observational study, including patients from private rheumatology clinics in three Central American countries (Guatemala, Honduras and Panama) and one in the Caribbean (Dominican Republic) Patients were enrolled between April 25th, 2018 and July 31st, 2019. Inclusion criteria: SpA diagnosis fulfilling ASAS classification criteria, age 18 - 45 years, sign informed consent and willing to perform protocol procedures during a single visit. Exclusions: any other rheumatic diseases, malignancy or HIV. Results: Each center identified 50 consecutive patients with $\mathrm{SpA}$. The main reason for exclusion from this analysis was not meeting the age requirement $(\mathrm{N}=94)$. Therefore, we analyzed 25 from Dominican Republic (DR), 25 from Guatemala, 32 from Honduras and 24 from Panama.

When applying ASAS axial and peripheral SpA definitions, all countries had high number of AS Patients. Subclinical classification by country showed the most frequent diagnosis was AS (64.1\%), followed by PsA (16\%), ReA $(9.4 \%)$, Undifferentiated SpA $(7.5 \%)$, IBD associated arthritis $(1.9 \%)$ and $\mathrm{Nr}-\mathrm{AxSpA}$ $(0.9 \%)(p<0.001)$; characteristics of patient population and sub-clinical classification by country, Table 1 . When clinical manifestations were classified as axial or peripheral $\mathrm{SpA}, 70.7 \%$ were axial in the four countries.

Table 1. Patient population characteristics and Sub-clinical classification by Country

\begin{tabular}{|c|c|c|c|c|c|c|}
\hline & & Dominican Republic & Guatemala & Honduras & Panama & Total \\
\hline \multirow{3}{*}{ Age Years } & Number patients & 25 & 25 & 32 & 24 & 106 \\
\hline & Mean Age & 32.48 & 32.28 & 33.66 & 32.71 & \\
\hline & SD & 8.45 & 7.63 & 8.91 & 6.34 & \\
\hline \multirow{2}{*}{ Gender } & Female & 6 & 9 & 13 & 8 & 36 \\
\hline & Male & 19 & 16 & 19 & 16 & 70 \\
\hline \multirow{2}{*}{ Place of living } & City & 1 & 14 & 26 & 20 & 61 \\
\hline & Rural/outside city & 24 & 11 & 6 & 4 & 45 \\
\hline \multirow{4}{*}{ Scholarity } & Elementary & 0 & 3 & 2 & 1 & 6 \\
\hline & High School & 7 & 5 & 17 & 4 & 33 \\
\hline & Middle School & 1 & 1 & 2 & 2 & 6 \\
\hline & \begin{tabular}{|l|} 
University \\
\end{tabular} & 17 & 16 & 11 & 17 & 61 \\
\hline $\begin{array}{c}\text { Smoking } \\
\text { Habit }\end{array}$ & Yes & 2 & 2 & 5 & 1 & 10 \\
\hline \multirow{6}{*}{$\begin{array}{c}\text { Sub-clinical } \\
\text { classification } \\
\text { by country }\end{array}$} & USpA & 1 & 5 & 1 & 1 & $08(7.5 \%)$ \\
\hline & ReA & 2 & 6 & 1 & 1 & $10(9.4 \%)$ \\
\hline & Nr-AxSpA & 0 & 1 & 0 & 0 & $01(0.9 \%)$ \\
\hline & AS & 19 & 7 & 26 & 16 & $68(64.1 \%)$ \\
\hline & $\begin{array}{l}\text { IBD associated } \\
\text { arthritis }\end{array}$ & 1 & 1 & 0 & 0 & 02 (1.9\%) \\
\hline & PSA & 2 & 5 & 4 & 6 & $17(16 \%)$ \\
\hline
\end{tabular}

SD or $\pm=$ Standard DeviationUndifferentiated SpA (USpA), Reactive Arthritis (ReA), Nonradiographic Axial SpA (Nr-AxSpa), (AS), Inflammatory Bowel Disease-Associated Arthritis (IBD), Psoriatic Arthritis (PsA) 